\title{
HKI PADA BATIK TULIS INDONESIA (STUDI KASUS BATIK TULIS TANJUNG BUMI, MADURA)
}

\author{
Indah Purnama Sari, Universitas Indraprasta PGRI \\ zaenimiftah02@gmail.com \\ Siswi Wulandari, Universitas Indraprasta PGRI \\ dedensy@telkomuniversity.ac.id \\ Siska Maya, Universitas Indraprasta PGRI \\ dedensy@telkomuniversity.ac.id
}

\begin{abstract}
ABSTRAK
Kajian ini bertujuan untuk mengetahui hak kekayaan intelektual (HKI) yang dapat diberikan pada batik Tanjung Bumi, HKI yang telah digunakan, kendala-kendala dalam memberikan perlindungan HKI, serta usaha yang telah dilakukan oleh dinas terkait. Penelitian ini adalah penelitian deskriptif dengan pendekatan kualitatif. Teknik pengumpulan data menggunakan wawancara, observasi, dan dokumentasi. Subjek penelitian berjumlah delapan orang dengan teknik snow ball. Analisis data meliputi data reduction, data display, dan conclusion atau verification. Simpulan kajian ini adalah bahwa HKI yang dapat dipergunakan pada batik Tanjung Bumi adalah hak cipta, hak merek, hak paten, dan hak indikasi geografis. HKI yang telah digunakan selama ini adalah hak merek. Adapun kendala dalam pemberian perlindungan HKI pada batik Tanjung Bumi adalah: 1) terbatasnya pengetahuan para perajin batik tentang HKI; 2) rendahnya tingkat perekonomian perajin batik, 3) prosedur pengurusan HKI rumit dan mahal, dan 4) mematenkan motif dianggap pekerjaan yang sia-sia. Upaya yang telah dilakukan oleh dinas terkait adalah melakukan edukasi dan pendekatan secara personal kepada UKM-UKM batik untuk mengurus HKI terkait merek, agar mendapatkan kemudahan untuk mengembangkan usahanya di kemudian hari.
\end{abstract}

Kata Kunci: Hak Kekayaan Intelektual, Batik Tanjung Bumi

\begin{abstract}
This study aims to determine the intellectual property rights (IPR) that can be given to batik Tanjung Bumi, IPR that has been used, the constraints in providing IPR protection, as well as efforts that have been done by the relevant agencies. This research is descriptive research with qualitative approach. Techniques of collecting data using interviews, observation, and documentation. Research subjects amounted to eight people with snow ball technique. Data analysis includes data reduction, display data, and conclusion or verification. The conclusion of this study is that IPR that can be used in Tanjung Bumi batik is copyright, trademark, patents, and geographical indication rights. The possible patents to be used are patents of natural dyes batik. IPR that has been used so far is the right of brand.
\end{abstract}


The obstacles in the provision of IPR protection on Tanjung Bumi batik are: 1) limited knowledge of batik artisans about IPR;2) the low level of batik crafters' economy, 3) the procedure of handling IPR is complicated and expensive, and 4) patenting the motive is considered a futile job. Efforts that have been made by the relevant agencies is educating and approach personally to batik SMEs to take care a right of brand, in order to get easy to expand its business in the future.

Keywords: Intellectual Property Rights, Batik Tanjung Bumi.

\section{PENDAHULUAN}

Sebagai sebuah mahakarya, batik saat ini tidak hanya diakui oleh masyarakat Indonesia tetapi juga telah diakui dunia. Tanggal 2 oktober 2009 menjadi tanggal bersejarah bagi Indonesia, karena batik telah ditetapkan sebagai Warisan Kemanusiaan untuk Budaya Lisan dan Nonbendawi (Masterpieces of the Oral and Intangible Heritage of Humanity). Pada akhirnya tanggal 2 Oktober ditetapkan sebagai Hari Batik oleh Pemerintah Indonesia. Tentu saja, semenjak diakuinya batik sebagai warisan dunia, pamor dan pangsa pasar batik di dalam negeri terdongkrak. Situasi ini menjadi angin segar bagi banyak wirausahawan yang bergerak dibidang batik, baik dalam profesinya sebagai perajin batik, pengelola museum batik, pelaku industri batik skala besar maupun industri batik rumahan. Namun di sisi lain, terdapat banyak kendala industri batik dalam negeri, diantaranya adalah harus bersaing dengan produk batik dari negara lain terutama dari Cina dengan harga yang jauh lebih murah karena mereka menggunakan teknologi tinggi dalam memproduksi batik serta adanya pembebasan bea masuk (Sudantoko, 2011).

Sebagian masyarakat Indonesia terkendala dalam memaknai dan memahami hak kekayaan intelektual serta regulasinya karena keadaan ekonomi bangsa Indonesia yang masih berada jauh dari tingkat pendapatan perkapita masyarakat negara-negara maju. Akibatnya, masyarakat industri kecil sering dirugikan, karena mereka dianggap melanggar ketentuan tentang HKI walaupun sebetulnya karya-karya yang mereka buat adalah hasil dari ciptaan mereka sendiri. Bahkan karena pengaruh kultur dan agama, beberapa anggota masyarakat beranggapan bahwa membagikan ilmu dan temuan mereka kepada orang lain merupakan perbuatan yang mulia. Sayangnya, kemudian keluguan dan "kemuliaan" hati tersebut dimanfaatkan secara tidak bertanggung jawab oleh pihak lain, yang berakibat karya dan temuan-temuan sebagian masyarakat Indonesia kemudian "dicuri" oleh orang lain. Penjiplakan biasa terjadi pada sesama pembatik secara perorangan, usaha batik skala kecil menengah, industri batik skala besar, hingga penjiplakan dan pengakuan hak kekayaan intelektual terhadap suatu motif batik oleh negara lain.

Hal lain yang sering menjadi masalah adalah keterjangkauan harga. Sebagaimana diketahui batik tulis tergolong produk dengan harga tinggi karena proses pembuatan yang manual, sedangkan batik printing dikerjakan oleh mesin dalam jumlah besar sehingga harganya juga lebih murah. Hal ini berakibat batik tulis menjadi kurang diminati masayarakat karena harganya yang cukup tinggi. 
Indonesia memiliki banyak sentra batik di berbagai wilayah, termasuk Pulau Madura. Salah satunya, lumbung batik di Kecamatan Tanjung Bumi Kabupaten Bangkalan. Seperti halnya batik Madura yang lain, Batik Tanjung Bumi Madura memiliki kekhasan atau karakteristik yang unik namun belum dikenal secara luas serta belum berkembang dengan baik.

Tujuan yang ingin dicapai dalam penelitian ini adalah untuk mengetahui macam HKI yang dapat melindungi karya perajin batik tulis Tanjung Bumi, mengetahui HKI apa saja yang telah digunakan, mengidentifikasi kendala yang ditemukan dalam usaha memberikan hak kekayaan intelektual terhadap karyakarya perajin batik, dan mengidentifikasi usaha yang telah dilakukan oleh instansi terkait untuk mengatasi kendala-kendala tersebut.

Hasil penelitian ini diharapkan dapat memberikan manfaat bagi masyarakat pelaku industri termasuk industri kecil/UKM, home industry, dan para perajin batik menumbuhkan kesadaran mengenai belum cukup terlindunginya hak kekayaan intelektual atas karya-karya batik perajin batik tulis Tanjung Bumi. Diharapkan selanjutnya pemerintah daerah ataupun instansi yang terkait dapat melakukan pembinaan, serta pendampingan terhadap para perajin batik dalam perlindungan hak kekayaan intelektual atas karya mereka, mengingat karya dan temuan mereka merupakan sebuah mahakarya dengan nilai jual yang tinggi.

Indonesia adalah salah satu negara peserta perjanjian pembentukan WTO. Sebagai konsekuensi dari keikutsertaan, terutama yang terkait dengan perjanjian atau konvensi internasional di bidang Hak Kekayaan Intelektual (HKI), adalah dibuatnya regulasi tentang perlindungan terhadap karya intelektual manusia. Hak kekayaan intelektual di Indonesia masih menjadi suatu permasalahan, karena di satu sisi berkaitan dengan masalah liberalisasi ekonomi, dan di sisi lain berhadapan dengan kondisi sosial, budaya, ekonomi masyarakat. Kondisi sosial budaya masyarakat Indonesia masih berada dalam masa transisi masyarakat industrial dan belum semuanya mengerti dan memahami masalah-masalah HKI (Widihastuti \& Kusdarini, 2013).

Hak Kekayaan Intelektual (HKI) adalah suatu perlindungan hukum yang diberikan oleh Negara kepada seseorang dan atau sekelompok orang ataupun badan yang ide dan gagasannya telah dituangkan ke dalam bentuk suatu karya cipta (berwujud) (Jayadi \& Cahyadi, 2015). Berdasarkan definisi tersebut, suatu karya cipta berhak dilindungi secara hukum, apabila telah didaftarkan sesuai dengan persyaratan yang ada. HKI meliputi kehidupan teknologi, ilmu pengetahuan, maupun seni dan sastra. Ruang lingkup HKI yang cukup luas ini meliputi berbagai macam hak yang timbul dari adanya produk-produk hasil pemikiran manusia. Dengan demikian, pemilikan HKI bukan terhadap barangnya melainkan terhadap hasil kemampuan intelektual manusianya dan berwujud. Jadi HaKI melindungi pemakaian ide, gagasan dan informasi.

Jenis hak kekayaan intelektual terbagi menjadi dua, yaitu hak cipta dan hak kekayaan industri. Ketua Pusat Studi HKI, FH UII, Budi Agus Riswandi menyampaikan, hak cipta melekat pada sebuah benda saat benda tersebut diciptakan. Fungsinya adalah untuk menetapkan keaslian karya agar tidak bisa ditiru secara sembarangan (Muhammad, 2015). 
Hak kekayaan industri terbagi lagi menjadi beberapa bagian seperti paten, merek, rahasia dagang, desain industri, tata letak sirkuit terpadu, dan indikasi geografis. Hak Cipta (Copyrights) diatur oleh UU No. 19 tahun 2002 tentang Hak Cipta. Hak Paten (Patent) diatur dalam UU No. 14 tahun 2001 tentang Paten. Hak Merek (Trademark) diatur dalam UU No. 15 tahun 2001 tentang Merek. Rahasia Dagang (Trade Secrets) diatur oleh UU No. 30 tahun 2000 tentang Rahasia Dagang. Desain Industri (Industrial Design) diatur oleh UU No. 31 tahun 2000 tentang Desain Industri. Desain Tata Letak Sirkuit Terpadu (Circuit Layout) UU No. 32 tahun 2000 tentang Desain Tata Letak Sirkuit Terpadu. Adapun Perlindungan Varietas Tanaman (Plant Variety) diatur dalam UU No. 29 tahun 2000 tentang Perlindungan Varietas Tanaman (Jayadi \& Cahyadi, 2015).

Pengurusan HKI tidak bersifat memaksa, seseorang bebas untuk mengajukan permohonan atau mendaftarkan karya intelektualnya atau tidak. Adanya HKI dimaksudkan sebagai penghargaan atas suatu hasil karya dan sebagai stimulus bagi orang lain untuk melakukan pengembangan lebih lanjut dan atau untuk memberi nilai tambah. Menghadapi pasar global, kepemilikan HKI menjadi salah satu instrumen yang sangat penting untuk melindungi pelaku usaha dari tindakan-tindakan yang merugikan misalnya 'pencurian' atau 'pengakuan' atas ide, pemikiran, teknologi, maupun kreativitas. Dengan kepemilikan HKI seseorang telah memiliki kepastian hukum ketika ada pengusaha lain yang akan meniru dengan struktur yang sama.

Contoh masalah yang terkait dengan HKI adalah mulai banyak bermunculan batik printing khas suatu daerah yang diproduksi oleh daerah lain. Sebagaimana dilansir dari republika.co.id (22 Juni 2015), para perajin batik Sleman, menuntut Pemkab Sleman untuk memberikan perlindungan berupa HKI karena bermunculan batik printing khas Sleman yang diproduksi daerah lain. Menurut Ketua Asosiasi Pembatik Sleman, Tanti Syarif, produksi tanpa izin tersebut dapat mengancam kelangsungan perajin rumahan di Sleman. Hal ini disebabkan harganya jauh lebih murah dan dimotori oleh pengusaha bermodal besar. Oleh karena itu, Tanti Syarif merasa perlu adanya prosedur khusus untuk melaksanakan pembuatan batik khas Sleman agar tidak merugikan para perajin batik (Muhammad, 2015).

Menurut Deputi Fasilitasi Hak Kekayaan Intelektual (HKI) \& Regulasi Badan Ekonomi Kreatif (Bekraf), Ari Juliano Gema, ada tiga unsur yang identik dengan batik, yakni teknik, teknologi yang digunakan dan motifnya. Namun, karena keterbatasan maka hanya motif batik yang dilindungi Hak Kekayaan Intelektual (HKI) (Triananda, 2015). Salah satu alasannya adalah, karena teknik membatik menggunakan malam sebenarnya juga pernah dipergunakan pada beberapa peradaban sebelumnya, adapun motif erat kaitannya dengan budaya lokal yang umumnya berciri khas dan berbeda-beda. Batik Tanjung Bumi yang merupakan batik pesisir, identik dengan motif bernuansa pesisir, misal kerang, sulur rumput laut, cumi-cumi, ombak, dan sebagainya.

Beberapa perlindungan terkait motif menurut Ari Julianto Gema (Triananda, 2015) adalah : Para perajin batik yang mendaftarkan hak cipta atas motif batik yang sudah dibuat di Indonesia dan negara lain dimana produk mereka dipasarkan, akan mendapatkan perlindungan secara hukum seandainya 
motif batik mereka dibajak, dicuri atau digunakan secara tidak sah. Adapun jika motif batik merupakan hasil karya turun temurun yang sudah tidak diketahui lagi pencipta motifnya dan dipelihara secara komunal, maka hak cipta atas motif batik tersebut dipegang oleh negara. Jika motif batik hasil karya perorangan yang masih diketahui pencipta motifnya, maka hak ciptanya dipegang oleh orang yang bersangkutan. Dan dilindungi seumur hidup penciptanya ditambah 70 tahun setelah penciptanya meninggal dunia.

Adapun menurut hasil penelitian Setiati Widihastuti dan Eny Kusdarini (2013), bahwa hak kekayaan intelektual yang dapat digunakan pada hasil karya batik meliputi hak cipta, hak paten sederhana, hak merek, dan hak indikasi geografis.

\section{METODE PENELITIAN}

Metode penelitian yang digunakan adalah metode kualitatif. Situasi sosial yang diteliti berlokasi di Kecamatan Bangkalan dan Kecamatan Tanjung Bumi. Keduanya terletak di Kabupaten Bangkalan, Madura, Jawa Timur. Situasi sosial terdiri dari lembaga pemerintah, yaitu Departemen Perindustrian dan Ketenagakerjaan Kabupaten Bangkalan dan sentra industri batik tulis yang tersebar di beberapa desa di Kecamatan Tanjung Bumi.

Dalam penelitian ini sampel sumber data dipilih secara purposive dan bersifat snowball sampling. Sampel sumber data pada tahap awal memasuki lapangan merupakan orang yang dinilai memiliki kekuatan dan otoritas pada situasi sosial atau obyek yang diteliti, sehingga mampu memberi rekomendasi kemana saja peneliti akan melakukan pengumpulan data. Sampel sebagai sumber data atau sebagai informan harus memenuhi criteria sebagai berikut: menguasai dan menghayati kegiatan yang sedang diteliti, masih berkecimpung atau terlibat pada kegiatan yang sedang diteliti, dan memiliki waktu yang memadai untuk dimintai informasi. Adapun yang menjadi sumber data pertama adalah Staf Disprinaker Kabupaten Bangkalan.

Teknik pengumpulan data dalam penelitian ini adalah triangulasi atau gabungan dari ketiga teknik pengumpulan data, yaitu : observasi, wawancara mendalam, studi dokumentasi. Analisis data dalam penelitian kualitatif dilakukan pada saat pengumpulan data berlangsung, dan setelah selesai pengumpulan data dalam periode tertentu. Pada penelitian ini analisis data mengikuti model Miles and Huberman (Sugiyono, 2010). Analisis data dilakukan secara interaktif dan berlangsung terus menerus hingga data jenuh. Aktivitas dalam analisis data yaitu peneliti melakukan data reduction, data display, dan conclusion atau verification.

Uji keabsahan data meliputi uji kredibilitas data (validitas internal), uji dependabilitas (reliabilitas) data, dan uji transferabilitas (validitas eksternal/ generalisasi). Uji kredibilitas dilakukan dengan memperpanjang masa pengamatan, meningkatkan ketekunan, triangulasi, diskusi teman sejawat, mengadakan member check, menggunakan bahan referensif. Uji dependability dilakukan oleh auditor dari pihak LPPM Universitas Indraprasta PGRI. Peneliti memiliki rekam jejak aktivitas lapangan, sehingga dependabilitas penelitian dapat dipercaya. Uji transferability dilakukan dengan cara membuat laporan penelitian secara rinci, jelas, sistematis, dan dapat dipercaya. Pembaca laporan 
penelitian memperoleh gambaran yang jelas dan gamblang tentang bagaimana suatu hasil penelitian dapat diberlakukan di tempat lain, sehingga hasil penelitian telah memenuhi standar transferability.

\section{HASIL PENELITIAN DAN PEMBAHASAN}

\section{Desa Telaga Biru, Asal Mula Batik Tanjung Bumi}

Sentra batik di Madura tersebar di pesisir pulau yang memiliki luas 5304 kilometer persegi mulai dari Bangkalan, Sampang, Pamekasan, hingga Sumenep. Hampir setiap kabupaten di Pulau Madura ini memiliki batik dengan ciri khas tersendiri. Salah satu sentra kerajinan batik di Madura terletak di Kecamatan Tanjung Bumi, Kabupaten Bangkalan. Batik Tanjung Bumi memiliki riwayat tersendiri. Menurut hasil wawancara dengan Bapak Camat Tanjung Bumi, asal mula batik Tanjung Bumi adalah dari Desa Telaga Biru, Kecamatan Tanjung Bumi. Dahulu batik menjadi pekerjaan perempuan di daerah ini untuk mengisi waktu luang menunggu suami mereka yang bekerja sebagai pelaut pergi ke daerah yang jauh, seperti ke pulau Kalimantan dan Sulawesi. Bagi kehidupan seorang istri yang suaminya seorang pelaut, menunggu kedatangan suami merupakan saat-saat paling panjang dan menegangkan. Seorang istri akan selalu gelisah menantikan apakah suaminya bisa pulang kembali dengan selamat dan bisa membawa uang untuk biaya rumah tangga atau justru tidak akan pernah kembali. Untuk mengurangi rasa gelisah tersebut, akhirnya istri-istri pelaut ini mulai belajar membatik. Riwayat batik tulis Tanjung Bumi ini diceritakan secara turun temurun dan belum ditemukan literatur yang menerangkan waktu kemunculannya secara tepat.

Dahulu, di daerah Tanjung Bumi batik digunakan untuk simpanan yang diperlakukan sebagai emas atau tabungan. Batik disimpan untuk diserahkan kepada anak dan cucu, sebagai tanda kasih dan cinta ibu. Batik menjadi salah satu sumber kekayaan dan kebanggaan mereka. Kini, nilai ini semakin bergeser karena zaman, membatik bukan lagi sebagai tanda kasih dan cinta ibu, namun juga untuk mencari uang. Orientasi para pembatik adalah untuk mendapatkan uang, sehingga nilai komersial ini menjadi salah satu sebab mengapa hasil penggarapan batik tidak lagi sebagus yang dahulu.

Kegiatan yang dilakukan untuk membunuh waktu itu sekarang menjadi industri rakyat. Tanjung Bumi menjadi kecamatan terbesar di Madura yang memproduksi batik, dan popularitasnya mulai dikenal penggemar batik Tanah Air.

\section{Ciri Khas Batik Tulis Tanjung Bumi}

Batik Tanjung Bumi memiliki motif khas batik pesisir yaitu terlihat dari warna-warna yang berani dan desain atau corak yang bebas, teknik pewarnaan yang tajam atau dikenal dengan istilah ngejreng. Warna yang paling menjadi ciri khas adalah dasar merah (mera), dasar biru indigo (biru dongker), dasar putih (tarpote), serta warna-warna elegan seperti hitam dan coklat. Selain itu, apapun warna dasarnya umumnya terdapat pula warna-warna tertentu yang menjadi coletan khas yaitu merah, biru, dan hijau. Ciri pesisiran tampak pada motif yang memunculkan unsur laut seperti sisik ikan, kerang, gelombang laut, 
sulur rumput laut dan burung. Selain unsur laut motif yang lain adalah flora dan fauna, seperti kembang kopi, kucing, gajah, dan sebagainya. Dalam selembar kain bisa muncul warna yang kontras yang tidak ditemukan pada batik pedalaman ataupun pesisiran di Jawa. Ciri khas yang paling menonjol dari batik Tanjung Bumi adalah motif dan warna yang sangat ekspresif, kontras dan eksotis, terlihat dari coletan yang dominan menggambarkan kebebasan ekspresi para perajin batik dalam menuangkan daya imajinasinya diatas selembar kain batik.

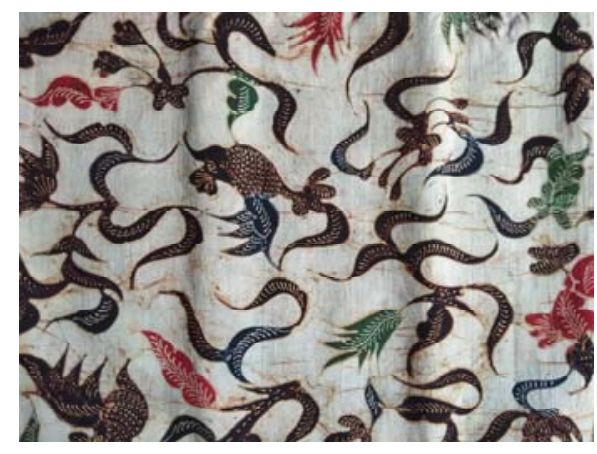

Gambar 1. Motif Burung

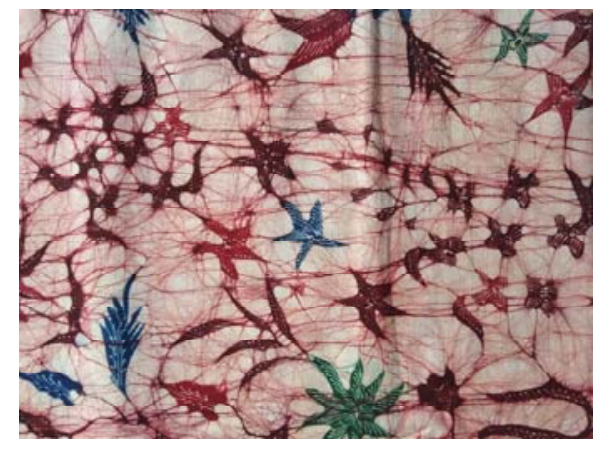

Gambar 2. Motif Bintang Laut

Cara atau proses pembatikan sama dengan daerah yang lain, namun karakteristik tanah dan air di daerah Tanjung Bumi dapat menjadi keunikan tersendiri dari daerah ini. Telah diyakini masyarakat bahwa pengobatan batik hanya berhasil jika dilakukan di empat desa, yaitu Desa Telaga Biru, Desa Macajah, Desa Tanjung Bumi, Desa Paseseh, keempatnya berada di wilayah Kecamatan Tanjung Bumi. Berdasarkan data dari Disperinaker, setidaknya terdapat 90 industri kecil batik tulis Kecamatan Tanjung Bumi yang bergerak khusus di bidang jasa pewarnaan, tersebar di 4 (empat) desa tersebut.

Tabel 1. Data Industri Kecil Batik Tulis Penerima Jasa Pewarnaan Kecamatan Tanjung Bumi

\begin{tabular}{lll}
\hline No & Desa & Jumlah \\
\hline 1 & Macajah & 4 \\
2 & Telaga Biru & 21 \\
3 & Paseseh & 16 \\
4 & Tanjung Bumi & 49 \\
& Jumlah & 90 \\
\hline
\end{tabular}

Sumber : Disperinaker Bangkalan, 2018

Keistimewaan yang lain dari Batik Madura dari Tanjung Bumi adalah warnanya akan lebih cerah dan bagus justru setelah beberapa kali dicuci. Semakin lama, kain batik menjadi semakin lembut dan warnanya semakin cerah. Tidak heran banyak motif batik tulis dari Tanjung Bumi yang harganya lebih mahal daripada batik Madura daerah lain. Perkembangan terbaru saat ini, Kecamatan Tanjung Bumi sedang menggalakkan batik pewarna alam, yang menggunakan bahan-bahan alami seperti kulit pohon, dedaunan, dan bekatul. 
Adapun untuk nama motif batik Tanjung Bumi juga memiliki kekhasan. Nama motif biasanya terkait dengan gambar apa dan cara pewarnaanya yang dikonsonankan dengan bahasa daerah setempat, misalnya ramo, banjar ramo, rongterong, perkaper, rawan, carcena, gaja se kerreng, bang kopi, serat kaju, panca warna, panji tukul, panji leko, panji susi, se'malaya, getoge, tor cettor, koceng renduh, dan lain-lain. Walaupun selembar kain batik ini memiliki nama motif, perajin batik enggan untuk mengurus hak cipta atas motif tersebut, karena setiap nama motif dapat dengan mudah untuk ditiru serta dimodifikasi menjadi motif baru. Memiliki hak cipta atas motif dipandang sebagai sesuatu yang mubadzir (sia-sia).

\section{Bahan dan Teknik Pembuatan Batik Tulis Tanjung Bumi}

Bahan yang digunakan dalam membuat batik tulis terdiri dari kain, lilin batik atau malam dan pewarna batik. Adapun peralatan yang digunakan dalam pembuatan batik tulis diantaranya adalah: canting, gawangan, kompor, wajan, bak celup, panci atau tong, bandul, taplak, saringan malam, dhingklik (tempat duduk), dan pisau.

Berikut ini adalah proses membatik yang berurutan dari awal hingga akhir. Penamaan atau penyebutan cara kerja di tiap daerah pembatikan bisa berbeda-beda, tetapi inti yang dikerjakannya adalah sama.

1. Nganji. Nganji merupakan tahap paling awal atau pendahuluan, diawali dengan mencuci kain mori kemudian dilanjutkan dengan memasukkan kain mori kedalam abu merang. Setelah itu kain diberi kanji dan dijemur. Selanjutnya kain mori dipalu untuk menghaluskan lapisan kain agar mudah dibatik.

2. Nyepat dan Ngeblat. Nyepat adalah membuat garis-garis dasar dengan menggunakan pensil dan penggaris panjang.

3. Reng-reng dan ngesse'en. Membatik merupakan cara menorehkan malam batik ke kain mori, dimulai dari reng-reng (menggambar motif) dan ngesse'en (mengisi pola dengan berbagai macam bentuk). Di dalam proses ngesse'en terdapat istilah nyecek, yaitu membuat isian dalam pola yang sudah dibuat dengan cara memberi titik-titik.

4. Nyolet. Nyolet adalah memberi warna pada bagian motif tertentu.

5. Nembok. Nembok adalah proses menutupi bagian-bagian yang tidak boleh terkena warna dasar dengan menggunakan malam.

6. Nyellup. Nyellup adalah proses pencelupan kain yang sudah dibatik ke cairan warna secara berulang-ulang sehingga mendapatkan warna yang diinginkan.

7. Nglorod. Dalam tahap ini, pembatik melepaskan seluruh malam (lilin) dengan cara memasukkan kain ke dalam air mendidih. Setelah diangkat, kain dibilas dengan air bersih dan kemudian diangin-anginkan hingga kering.

8. Ngeskes. Pada tahap ini, sisa malam pada kain yang sudah dilorod dikikis secara hati-hati dengan menggunakan pisau kemudian kain dibilas dengan air bersih dan diangin-anginkan. 


\section{HKI pada Karya Perajin Batik Tanjung Bumi}

Motif batik Tanjung Bumi digambarkan langsung ke atas kain. Dalam hal ini para perajin tidak merasa perlu menyimpan, mendokumentasikan, dan merahasiakan motif rancangannya. Mereka tidak mempermasalahkan karyakarya mereka yang ditiru orang lain. Kebutuhan hidup membuat para pembatik lebih menyukai bagaimana karya batik mereka terjual cepat untuk memenuhi kebutuhan sehari-hari, daripada memikirkan apakah karya mereka dijiplak atau tidak. Sebagian UKM yang telah berkembang mulai menyadari pentingnya mengurus HKI merek untuk kepentingan pengembangan usaha ke depan baik untuk mendapatkan bantuan permodalan hingga mendapat akses pemasaran ke luar negeri.

Pewarnaan batik tulis Tanjung Bumi sebagian menggunakan pewarna alam yang hingga kini tidak diketahui siapa penciptanya. Metode warna alam ini diwariskan secara turun menurun. Hasil dari pewarnaan alam jauh berbeda dengan pewarna kimia, karena pewarna alam menghasilkan warna-warna yang lembut dan awet. Batik yang menggunakan warna alam melalui proses pembuatan yang unik dan lama, yaitu batikannya dua kali (pada dua sisi kain mori). Batik warna alam ada pula yang direndam di dalam gentong selama tujuh bulan. Oleh karena itu kemudian dikenal dengan nama 'Batik Gentongan'. Harga batik Gentongan bisa mencapai jutaan rupiah. Namun sebagaimana batik dengan pewarnaan kimia, batik gentongan juga tidak akan bisa memberikan hasil warna dasar yang sama persis, karena keberhasilan pewarnaan dipengaruhi oleh banyak hal, salah satunya intensitas cahaya matahari. Batik warna alam saat ini sedang digalakkan oleh pemerintah daerah, karena merupakan tuntutan dunia internasional, syarat batik yang layak eksport adalah batik yang menggunakan bahan pewarna alam.

Berdasarkan paparan di atas, sebetulnya ada beberapa perlindungan hukum HKI yang bisa diterapkan pada batik Tanjung Bumi dalam berbagai macam ruang lingkup HKI. Bahkan satu produk bisa dilindungi oleh berbagai hak yang tercakup dalam hak kekayaan intelektual. Cakupan HKI yang bisa melindungi hasil mahakarya para pembatik Tanjung Bumi di antaranya adalah:

a. Hak cipta untuk desain motif batik yang baru, yang tidak merupakan modifikasi motif lama. Hal ini mengacu pada ketentuan Pasal 12 ayat 1 huruf i UU No. 19 Tahun 2002 tentang Hak Cipta dengan berbagai peraturan pelaksanaannya. Kreasi-kreasi dan ciptaan perajin batik dapat dilindungi oleh hak cipta, mengingat salah satu lingkup perlindungan hak cipta, di antaranya adalah seni batik. Dengan dilindunginya motif batik Tanjung Bumi tersebut, akan muncul hak eksklusif bagi perajin atau pencipta motif untuk mempublikasikan atau memperbanyak sendiri motif batik baru yang menjadi ciptaannya atau memberi ijin kepada pihak lain untuk itu. Sebetulnya perlindungan suatu ciptaan timbul secara otomatis sejak ciptaan diwujudkan dalam bentuk yang nyata, yakni berupa motif batik baru yang merupakan kreasi dari perajin dan tidak sekedar modifikasi dari motif lama (yang sudah ada). Walau pendaftaran hasil cipta bukan suatu kewajiban, pendaftaran ini tetap dibutuhkan agar pencipta motif memperoleh "surat pendaftaran ciptaan". Surat ini sangat urgen apabila perajin bermaksud untuk membuat perjanjian pengalihan hak cipta kepada orang lain. Surat pendaftaran ciptaan juga dapat dijadikan 
sebagai alat bukti awal di pengadilan apabila dikemudian hari timbul sengketa atas motif batik tersebut. Untuk bisa melakukan pendaftaran, para perajin perlu mendokumentasikan semua motif batik rancangannya dalam bentuk soft copy maupun hard copy.

b. Hak paten sederhana, terutama kreasi dalam pencelupan dan pewarnaan batik. Ini dikarenakan proses pembuatan pencelupan dan pewarnaan batik baik menggunakan pewarna kimia maupun pewarna alami, walaupun dilakukan dengan menggunakan teknologi sederhana, namun mempunyai nilai tinggi dan menghasilkan tata warna yang unik dan khas yang juga merupakan lingkup perlindungan paten. Agar dapat dilindungi dengan hak paten, harus dibuat suatu formula khusus proses pewarnaan batik yang akurat dan konsisten, mengingat takaran-takaran yang dipergunakan perajin batik Tanjung Bumi dalam mencampur bahan pewarna menggunakan ukuran-ukuran yang kurang terjamin tingkat akurasinya, misal: dengan memakai ukuran "segenggam", "seikat", "sesendok", dan sebagainya. Agar dapat diterapkan dalam suatu proses industri, para perajin dengan pendampingan dapat menyusun langkah-langkah pewarnaan secara detail dan mempergunakan takaran-takaran yang lebih akurat, misalnya menggunakan timbangan atau gelas ukur.

c. Hak merek dagang. Merek adalah identitas suatu produk yang memiliki daya pembeda dan digunakan dalam kegiatan perdagangan. Merek berfungsi sebagai tanda pengenal untuk membedakan suatu hasil produksi dengan hasil produksi lainnya. Merek juga berfungsi sebagai alat promosi. Pembeli melihat jaminan mutu juga berdasar merek. Cara mendapatkan merek dagang, apabila suatu unit usaha batik mendaftarkan kreasinya itu ke Ditjen HKI dengan menggunakan merek tertentu. Nama merek ini harus dipilih nama lain dan bukan mempergunakan motif batik sebagai merek dagang.

d. Hak atas indikasi geografis. Hak ini dapat diberikan karena adanya ciri-ciri tertentu yang hanya dimiliki dan hanya ada pada batik Tanjung Bumi. Sebagai contoh, motif batik Tanjung Bumi seringkali bernuansa laut, atau alam sekitar baik flora maupun fauna. Demikian juga dengan warna coletan yang khas. Pada batik tanjung Bumi selalu ditemukan warna coletan merah, biru, dan hijau. Coletan ini sangat menyala terkesan 'ngejreng' karena seringkali kontras dengan warna dasarnya. Batik Tanjung Bumi juga berbeda dalam hal kekuatan warna. Batik ini tidak mudah luntur, semakin lama justru semakin bagus warnanya. kekhasan ini tidak ditemukan pada batik lain walaupun sama-sama diproduksi di pulau Madura. Hal ini menjadikan motif batik yang artistik, menunjukkan Tanjung Bumi sebagai daerah asal atau indikasi geografis dari kreasi batik tersebut sehingga untuk motif-motif batik tertentu yang sangat "khas Tanjung Bumi" dapat didaftarkan ke Ditjen HKI unuk memperoleh perlindungan hak atas indikasi geografis.

\section{Kendala-kendala dalam Memberikan perlindungan HKI}

Kebanyakan para perajin batik Tanjung Bumi belum menganggap perlindungan HKI sebagai suatu kebutuhan dan mereka belum memandang urgen terhadap perundang-undangan di bidang HKI. Beberapa kendala dalam 
pemberian perlindungan hak kekayaan intelektual terhadap karya perajin batik Tanjung Bumi antara lain adalah:

a. Terbatasnya pengetahuan dan pemahaman para perajin batik Tanjung Bumi tentang hal-hal yang berkaitan dengan pendaftaran hak kekayaan intelektual yang sebetulnya diperlukan dan dapat melindungi karya batik mereka. Perajin tidak mengenal HKI, tidak dapat membedakan antara hak paten, hak merek, hak cipta. Semua jenis HKI dipersepsikan (disebut) sebagai hak paten. Rendahnya pengetahuan tentang HKI juga disebabkan rendahnya tingkat pendidikan para perajin, yang sebagian besar hanya mengenyam pendidikan sampai dengan Sekolah Dasar dan atau hanya sekolah mengaji (madrasah).

b. Rendahnya tingkat perekonomian para perajin. Sebagian perajin mengawali sebagai buruh batik, yakni bekerja pada pengusaha batik. Para buruh ini bekerja berdasarkan spesifikasi, ada yang khusus 'nyepat', 'rengreng', 'isen', 'nyolet', 'nyelup', hingga 'ngeskes' sebagaimana telah dijelaskan pada bagian proses membatik. Para buruh umumnya hanya menerima kain mori dari pengusaha, adapun malam, obat pewarna, canting, dan bahan bakar mereka menyiapkannya sendiri. Ada pula buruh yang mengerjakan semua proses batikan dari awal hingga akhir namun kemudian menitipkannya atau menjual hasil karyanya kepada para pengusaha (pengepul, pedagang). Ketidakmapuan menjual dan keterbatasan modal menjadikan para buruh memiliki ketergantungan kepada para pengusaha. Hal ini menyebabkan kondisi ekonomi para buruh batik relatif stagnan. Para perajin berpikiran "praktis" dan sederhana, yakni lebih memilih karya batiknya terjual cepat untuk memenuhi kebutuhan sehari-hari daripada memikirkan karya mereka dijiplak, dicuri, dan sebagainya. Para perajin tidak terlalu merespons terhadap gagasan HKI untuk memberi perlindungan atas karya-karya mereka.

c. Prosedur pengurusan HKI rumit dan mahal. Untuk dapat mendapatkan perlindungan paten, diperlukan langkah-langkah yang rumit, seperti penyusunan spesifikasi paten, klaim, dan lain-lainnya, yang kesemuanya itu sangat asing bagi para perajin. Selain itu, untuk memperoleh perlindungan paten, diperlukan biaya yang relatif tidak sedikit, baik untuk membayar annual fee, biaya pemeliharaan paten (yang apabila tidak dibayarkan, hak paten yang bersangkutan akan dianggap batal demi hukum), biaya konsultan, dan sebagainya. Semua itu akhirnya menjadi faktor-faktor yang menghambat para perajin untuk dapat memperoleh perlindungan $\mathrm{HKI}$ atas pengetahuan tradisional mereka.

d. Mematenkan motif batik dianggap pekerjaan yang sia-sia. Seorang pembatik yang menciptakan suatu motif tertentu tidak akan sanggup menjaga dan menghalangi motifnya dijiplak oleh orang lain. Hal ini karena coretan canting diatas selembar kain batik sangat ekspresif dan bebas berkreasi. Suatu motif tertentu dapat saja ditiru, namun umumnya dengan sedikit sentuhan coretan canting yang berbeda pada 'isin', hal ini justru akan melahirkan motif baru. Mengutip pernyataan pesimis dari seorang pembatik, "motif itu gampang ditiru dan gampang dimodif. Kalau sudah ditambah sedikit saja isin sudah jadi motif baru. Lantas berapa banyak motif yang harus saya patenkan, dan berapa besar biayanya? sia-sia”. 
Sebenarnya pemerintah daerah dan pihak-pihak yang peduli dengan HKI telah memberikan sosialisasi pentingnya HKI. Dinas terkait deperti Disperinaker bahkan melakukan pendekatan mendatangi UKM secara personal untuk mengajak mereka mengurus HKI, namun hasilnya belum menggembirakan karena sebagian besar menolak. Berdasarkan data dari Disperinaker Bangkalan, hingga tahun 2018 diketahui baru 6 (enam) usaha batik tulis yang telah mengurus HKI Merek, yaitu : Griya Batik, Pesona Batik, Batik Bunda, Batik Tresna Art, Batik Peri Kecil, dan Rose Batique.

Perlindungan HKI diperoleh harus melalui upaya-upaya tertentu sesuai dengan ketentuan perundang-undangan HKI. Prosedur pendaftaran atau pengurusan untuk mendapatkan perlindungan HKI yang tidak sederhana dan beban biaya yang tidak sedikit membuat "tawaran perlindungan HKI" tersebut tidak cukup menarik minat para perajin batik tulis Tanjung Bumi untuk mendapatkannya. Menurut para perajin, yang lebih mereka butuhkan saat ini adalah bantuan modal dan bantuan pemasaran dari pemerintah. Alur berpikirnya sederhana, yaitu bagaimana mereka bisa memenuhi kebutuhan sehari-hari dengan layak, terlebih dalam keadaan perekonomian yang cukup berat seperti dewasa ini, dimana pasar batik cenderung sepi.

Temuan lain yang menarik dari penelitian ini adalah, bahwa dinas terkait (Disperinaker Bangkalan) telah berhasil mengedukasi beberapa usaha batik tulis untuk mengimplementasikan suatu sistem perlindungan bagi konsumen batik dalam usaha pemasarannya dengan membuat "Batik Mark". Batik Mark ini semacam sticker atau penanda khusus yang membedakan batik Tanjung Bumi berdasarkan kategori pembuatan, yaitu : batik tulis, batik cap, dan batik kombinasi tulis dan cap. Terkadang, konsumen yang minim pengetahuan tentang batik tidak dapat membedakan ciri batik tulis, batik cap, dan batik kombinasi tulis dan cap. Dengan adanya batik mark maka konsumen mendapat perlindungan dan jaminan, akan mendapatkan kategori atau jenis batik yang sesuai dengan keinginan serta anggarannya. Hingga tahun 2018, batik mark sudah diimplementasikan oleh 5 (lima) usaha batik tulis, yaitu : Pesona Batik, Batik EQ Mari Marita, batik Tresna Art, Batik Peri Kecil, dan Batik At Thaya.

\section{SIMPULAN}

Simpulan kajian ini adalah bahwa HKI yang dapat dipergunakan pada batik Tanjung Bumi adalah hak cipta, hak merek, hak paten, dan hak indikasi geografis. HKI yang telah digunakan selama ini adalah hak merek, terdapat 6 (enam) usaha batik tulis Tanjung Bumi yang memiliki HKI merek. Adapun kendala dalam pemberian perlindungan HKI pada batik Tanjung Bumi adalah: 1) terbatasnya pengetahuan para perajin batik tentang $\mathrm{HKI}$; 2) rendahnya tingkat perekonomian perajin batik, 3) prosedur pengurusan HKI rumit dan mahal, dan 4) mematenkan motif dianggap pekerjaan yang sia-sia. Upaya yang telah dilakukan oleh dinas terkait adalah melakukan edukasi dan pendekatan secara personal kepada UKM-UKM batik untuk mengurus HKI terkait merek, agar mendapatkan kemudahan untuk mengembangkan usahanya di kemudian hari. Pemerintah pusat perlu mendorong pemerintah daerah untuk segera mengurus HKI yang dapat diterapkan pada batik tulis khas daerah agar tidak 
terulang kasus dimana hak paten proses pembuatan batik jatuh pada negara lain. Hak paten yang dapat diupayakan segera saat ini adalah hak paten untuk batik pewarna alam, sehingga dunia mengakui bahwa batik pewarna alam adalah milik Indonesia, satu diantaranya Batik Tulis Tanjung Bumi.

\section{UCAPAN TERIMA KASIH}

Apresiasi dan terima kasih kepada Direktorat Riset dan Pengabdian Masyarakat, Dirjen Penguatan Riset dan Pengembangan, Kementerian Riset, Teknologi dan Pendidikan Tinggi yang telah membiayai kegiatan Penelitian Dosen Pemula (PDP) Tahun 2018 dengan Judul : "Pengaruh Implementasi Hak Kekayaan Intelektual pada Batik Tulis Indonesia Ditinjau dari Segi Ekonomi”. Terima kasih juga kepada LLDIKTI Wilayah III Jakarta dan Lembaga Penelitian dan Pengabdian Masyarakat Universitas Indraprasta PGRI yang telah membantu kegiatan penelitian ini melalui Kontrak Penelitian: 032/K3/PNT/2018, Tanggal 6 Maret 2018. Dan Surat Perjanjian/ Kontrak Penelitian UNINDRA No : 0314/SKP.LT/LPPM/UNINDRA/III/2018 tanggal 12 Maret 2018.

\section{DAFTAR RUJUKAN}

Jayadi, K., \& Cahyadi, D. (2015). Sebuah Pengantar Memahami HKI dalam Desain. Makasar: Deskomvis FSD UNM Press.

Muhammad, D. (2015, Juni 22). Perajin Batik Sleman Tuntut Pemkab Bentuk HAKI. Retrieved April 19, 2018, from http://nasional.republika.co.id: http://nasional.republika.co.id/berita/nasional/daerah/15/06/22/nqck4aperajin-batik-sleman-tuntut-pemkab-bentuk-haki.

Sudantoko, D. (2011). Strategi Pemberdayaan Usaha Skala Kecil Batik di Pekalongan. Jurnal Eksplanasi Vol 6 No 1 Maret, 29-45.

Sugiyono. (2010). Metode Peneitian Pendidikan Pendekatan Kuantitatif, Kualitatif dan $R \& D$. Bandung: Alfabeta.

Triananda, K. (2015, Oktober 26). Perajin Batik Diimbau Daftarkan Hak Cipta Atas Motif Batik Buatannya. Retrieved April 20, 2018, from Berita Satu: http://www.beritasatu.com/ekonomi/317482-perajin-batik-diimbaudaftarkan-hak-cipta-atas-motif-batik-buatannya.html.

Widihastuti, S., \& Kusdarini, E. (2013). Kajian Hak Kekayaan Intelektual Karya Perajin Batik Studi Kasus di Desa Wukisari Imogiri Bantul. Jurnal Penelitian Humaniora Vol 18 No 2 Oktober , 145-155. 
